\title{
Som man roper i skogen...
}

I Språkspalten i Tidsskriftet nummer 3/2011 etterlyste vi i redaksjonen en norsk oversettelse av termen «forest plot» (1). Et «forest plot» er et diagram som fremstiller til dels kompliserte statistiske sammenhenger på en visuelt enkelt forståelig måte, som regel i forbindelse med metaanalyser (fig 1). Slike diagram har også vært i bruk i Tidsskriftet (2).

\section{Engasjerte lesere}

Det er tydelig at både statistiske problemstillinger og norsk medisinsk fagspråk er noe som engasjerer, for etterlysningen har gjennom flere måneder avfødt en lang rekke kreative forslag fra Tidsskriftets lesere. Flere har ønsket å beholde skogbruksassosiasjonene som den engelske originaltermen gir, og har foreslått både «skogdiagram», «hogstdiagram», «teigdiagram», «skogteigdiagram» og «grenplot». Diagrammets karakteristiske utseende har gitt andre kolleger sportslige assosiasjoner fra både rosporten («regattaplot» eller «Tuftediagram» (etter roeren Olaf Tufte)) og friidretten («spyddiagram»). Diagrammets grafisk tydelige fordeling om en midtverdi har fått flere til å foreslå begreper som «vektstangdiagram», «midtlinjediagram», «balansediagram» og «resultatdiagram». Én kollegas assosiasjon har gått mer mot det som samler linjene: «glidelåsdiagram». En annen vil henlede på diagrammets mest sentrale element, det summerte estimatet, med forslaget «diamantdiagram». Innad i redaksjonen har vi også fått forslaget «metaanalysediagram».

\section{Assosiasjoner}

I denne rikholdige skogen av gode forslag har redaksjonen diskutert internt, og fått hjelp av både filologisk og statistisk ekspertise, i håp om å finne den aller mest dekkende norske termen. En direkte norsk oversettelse, «skogdiagram», yter originaltermen

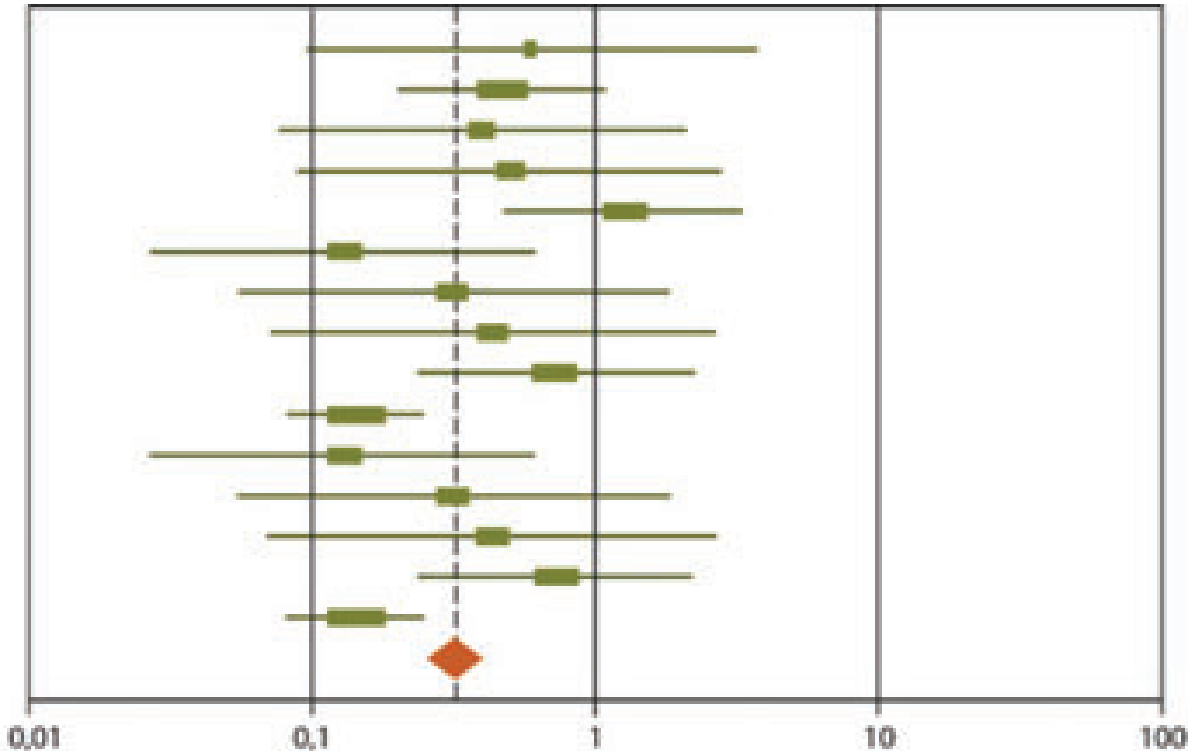

Figur 1 Forest plot. De horisontale linjene viser $95 \%$ KI for hver enkeltstudie, boksestørrelsen vekten, $x$-aksen oddsratio, diamanten det summerte estimat (1) rettferdighet, men gir assosiasjoner i retning av skogbruk mer enn av statistikk, og gir lite informasjon om hva diagrammet egentlig viser. De idrettsklingende termene har også det felles at de i liten grad gir assosiasjoner til diagrammets innhold. Siden diagrammet ikke bare benyttes i metaanalyser, men også for eksempel til subgruppeanalyser i store studier, er «metaanalysediagram» heller ikke helt dekkende.

\section{Balansediagram}

Etter disse diskusjoner har vi endt opp med «balansediagram» som det foreløpig mest dekkende forslaget. Det tydeliggjør poenget med diagrammet, nemlig å vise hvordan de ulike studiene balanserer, både mot det summerte estimat og mot oddsratioen. I tillegg gir det få andre assosiasjoner til andre former for grafisk statistikkpresentasjon, og det passer språklig inn blant andre norske termer for statistiske diagrammer, slik som søyle-, kake- og spredningsdiagram. Inntil videre kommer derfor denne type diagrammer til å benevnes balansediagram når de forekommer i Tidsskriftet.

\section{Are Brean}

are.brean@legeforeningen.no

Tidsskriftet

Are Brean (f. 1965) er ph.d. og spesialist i nevrologi. Han er medisinsk redaktør i Tidsskriftet og leder i Norsk nevrologisk forening.

Litteratur

1. Brean A. $0 m$ å se skogen... Tidsskr Nor Legeforen 2011; 131: 261

2. Larun L, Malterud K. Treningsbehandling ved kronisk utmattelsessyndrom. Tidsskr Nor Legeforen 2011; 131: 231-6.

Mottatt 15.7. 2011 og godkjent 11.8. 2011. Medisinsk redaktør Raida Ødegaard. 